\title{
COMPARISON OF CONSTITUTIONAL COURT AUTHORITY BETWEEN INDONESIA AND SOUTH KOREA
}

\author{
Janpatar Simamora \\ Law Faculty of HKBP Nommensen Medan University \\ E-mail: patarmora@yahoo.com
}

\begin{abstract}
This paper is intended to find out the comparison between Indonesian and South Korea constitutional court. Constitutional Court of Indonesia and South Korea have same authority, namely judicial review, the authority decide the disputes between state institutions and the dissolution of political parties. However, there are some differences. From the point of authority, Constitutional Court of Korea is more comprehensive because it has the constitutional complaint authority and in deciding the dispute of state institutions authority, the dispute type of the state institutions authority is classified explicitly. But from the point of judicial review execution, the constitutional court in Indonesia is more comprehensive because the applicant could be more flexible. Indonesian Constitutional Court should be able to adopt the excellence of Constitutional Court of Korea while maintaining it's excellence to maximize the Constitutional Court as escort agencies and interpreter of the Constitution.
\end{abstract}

Keywords: judicial review, constitutional complaint, constitutional court.

\begin{abstract}
Abstrak
Tulisan ini dimaksudkan untuk mengetahui bagaimana sesungguhnya perbandingan antara peradilan konstitusi Indonesia dengan Korea Selatan dengan melihat sejumlah persamaan dan perbedaannya. Pada dasarnya, peradilan konstitusi Indonesia dan Korea Selatan memiliki sejumlah persamaan, yaitu kewenangan judicial review, memutus sengketa kewenangan lembaga negara dan memutus pembubaran partai politik. Namun demikian, terdapat sejumlah perbedaan mendasar. Dikaji dari sudut kewenangan, Mahkamah Konstitusi Korea Selatan memiliki kewenangan lebih komprehensif karena memiliki kewenangan constitutional complaint dan dalam pelaksanaan kewenangan memutus sengketa kewenangan lembaga negara, jenis sengketa kewenangan lembaga negara diklasifikasikan secara eksplisit. Namun demikian, dari sudut pelaksanaan kewenangan judicial review, Mahkamah Konstitusi Indonesia lebih komprehensif karena pihak-pihak yang dapat menjadi pemohon lebih fleksibel. Seyogianya, peradilan konstitusi Indonesia dapat mengadopsi keunggulan yang dimiliki Mahkamah Konstitusi Korea Selatan dengan tetap mempertahankan keunggulan yang dimiliki guna memaksimalkan Mahkamah Konstitusi sebagai lembaga pengawal dan penafsir konstitusi.
\end{abstract}

Kata kunci: judicial review, pengaduan konstitusional, peradilan konstitusi.

\section{Introduction}

The establishment of Constitutional Court (MK) in Indonesia, in particular by adopting a judicial review authority as one of judiciary constitutional authority should be interpreted as an effort to strengthen the embodiment of a state law that puts the constitution as the highest law. ${ }^{1}$ The embodiments of the legal state of

Janpatar Simamora, "Analisa Yuridis Terhadap Model Kewenangan Judicial Review di Indonesia”, Jurnal of Mimbar Hukum, Vol. 25 No. 3 October 2013, Yogyakarta: Law Faculty of Gadjah Mada University, page 389.
Indonesia as defined by Article 1 line (3) NRI Constitution of 1945 can be realized when the administration state used rules and norms in the Republic of Indonesia (NRI) Constitution of $1945 .^{2}$

Institutionally, the existance of MK has completed the judicial power, where previously that the implementing agencies of judicial po-

Janpatar Simamora, "Tafsir Makna Negara Hukum dalam Perspektif Undang-Undang Dasar Negara Republik Indonesia Tahun 1945", Jurnal Dinamika Hukum, Vol. 14 No. 3 September 2014, Purwokerto: Law Faculty of Jenderal Soedirman University, page 547. 
wer in Indonesia is only held by the Highest Court (MA). Based on Article 24 paragraph (2) NRI Constitution of 1945 stated that the judicial power is done by the Supreme Court and judicial bodies underneath it in the general courts, religious courts, military courts, State Administration (TUN) judicial and by the Court.

An efforts to adopt the Constitutional Court in Indonesia constitutional system conducted on the third amendment of 1945. Based on Article 24C paragraph (1) NRI Constitution of 1945, MK has four powers, including to judge the first and last decision which is the final result to test the laws against the Constitution or judicial review, cut on the dispute authority of state institutions which is granted by the Constitution, dissolution of political parties and the dispute election results.

Besides the constitutional authority, the Constitutional Court also has a constitutional obligation in the form of give the voice decision of Parliament on alleged violations by the President and/or Vice President by the Constitution. In line with the constitutional dynamics in recent years, the authority of the Constitutional Court are expanded in the form of maintain the disputed local election.

Since 2003, the Court is actively running the whole authority. Scrutiny of the maintaining cases statistics in the Court so far, it can be mentioned that all of the constitutional authority, the authority testing of the Act against the Constitution or judicial review authority which has the most response from various parties. Number of cases which is received by judicial review so far has reached more than 800 cases $^{3}$ while the number of cases in the field of other authorities statistics were less than the number of judicial review cases.

Regardless of the statistical difference in the number of cases in each constitutional authority of the Constitutional Court, the most important thing that should be interpreted wisely

\footnotetext{
3 Mahkamah Konstitusi, "Rekapitulasi Perkara Pengujian Undang-Undang", available on web http://www.mahkamahkonstitusi.go.id/index.php?page=web. RekapPUU, accessed on November, $14^{\text {th }} 2015$.
}

is that the existence of the Constitutional Court itself has been demonstrated through the process of handling the cases. This fact that make the various parties to continue to encourage more the Court to be able to maintain the independence and objectivity in dealing with any cases which maintain the authority.

Based on the historical record of the founder, the existence of Indonesian Constitutional Court itself is influenced by South Korean constitutional court models very much. Most of the authority of Korean Constitutional Court as South Korean constitutional court is adopted in the judicial authority model of the Indonesian constitution. This paper is intended in order to know how exactly the comparison of Indonesia and Korea or South Korean Constitutional Court.

The comparison of a constitutional court in both countries is expected to be known in a certain through this paper journal, in particu-lar by looking at a number of aspects of the strengths or advantages of the judicial authority of the South Korean constitution. Various advantages owned by South Korean constitutional court needs to be understood carefully related to the more qualified of Indonesian constitutional courts construction. However, the advantages of South Korean constitutional court is important to be studied to make the corrections within the framework as an efforts to improve the Court in Indonesia. This is why the writer tend to know the comparison of authority between Indonesia and South Korean constitutional court.

\section{Discussion \\ Indonesian Constitutional Justice}

A constitutional court in Indonesia has four constitutional authority, those to test laws against the Constitution, cut off the dispute of state institutions authority, cut off political parties dissolution and to decide disputes election results. Based on those authority, the Constitutional Court often referred to the enforcer, ${ }^{4}$ the

4 Martha Pigome, "Implementasi Prinsip Demokrasi dan Nomokrasi dalam Struktur Ketatanegaraan RI Pasca Amandemen UUD 1945," Jurnal Dinamika Hukum, Vol. 11 No. 2, May 2011, Purwokerto: Law Faculty of Jenderal Soedirman University, page 335. 
constitutions guardian or the the interpreter of constitution.

Through the authority implementation, the constitution is expected to be executed consistently, consequenly and responsibly by state officials. Thus, in principle, have consequences where the Court interpreted as a highest interpreter institution of the constitution. The position of Constitutional Court is intended to ensure the constitution as the constitution of the activities carried out and enforced in the state administration.

An attempts to follow up the provision of Article 24C paragraph (1) NRI Constitution of 1945 as a basis for the constitutionality of the Constitutional Court authority, established the Law 24 Year 2003 regarding to the Constitutional Court which converted into Law No. 8 of 2011 on the Amendment of the Act No. 24 of 2003 regarding to the Constitutional Court. Based on the dynamics of its development, Law 8 of 2011 on the Amendment of the Act No. 24 of 2003 about the Constitutional Court is never changed through the Government Regulation 1 of 2013 concerning the Second Amendment to Law No. 24 of 2003 regarding to the Constitutional Court.

Furthermore, Government Regulation No. 1 of 2013 concerning the Second Amendment to Law No. 24 Year 2003 regarding the Constitutional Court passed into Law No. 4 Year 2014 concerning the Government Regulation in Lieu of Law Stipulation No. 1 Year 2013 concerning the Second Amendment to Law No. 24 Year 2003 regarding the Constitutional Court become law. But then, through Court decision No. 1-2 / PUUXII / 2014, stated that Law No. 4 Year 2014 concerning the Stipulation perppu No. 1 Year 2013 concerning the Second Amendment to Law No. 24 Year 2003 regarding the Constitutional Court Become NRI contrary to the Constitution Act of 1945 and does not have binding legal force. Therefore, Law No. 24 of 2003 as amended by Act No. 8 of 2011 on the Amendment of the Act No. 24 Year 2003 regarding the Constitutional Court, applies back as before changed through the Government Regulations No. 1 in 2013.
Examined on the context of the parties that could have a legal personality or legal standing in each case under the authority of the Court, based on Article 51 paragraph (1) of the Constitutional Court. First, the applicant in the case of judicial review is the individual citizen; customary law community unit; public or private legal entities; or a state institution. Second, the applicant of the political parties dissolution, is the government. Third, in cut the election dispute, the applicant is an individual DPD candidate of election participants; candidates for President and Vice President of election participants; and the political parties contestant. Fourth, the rule on the dispute authority of state institutions, the applicant is a state institution whose authority is given by the Constitution and have a direct interest in the disputed authority. MK Regulation No. 8 of 2006 regarding to the Guidelines for Proceedings in the Constitutional Dispute Authority of State Institutions which can be affirmed that the applicant and the respondent is that the House of Representatives, the Assembly, the President, CPC, local government and other state institutions whose authorities are granted by the Constitution.

Regarding to the decision of the Court in any case under its authority is a final and binding result, therefore, when the decision of the Court have been read, the decision itself is valid and binding legal force. On that basis, it is not known any legal action against any decision of the Constitutional Court.

\section{Constitutional Justice in South Korea}

South Korea is a republic country founded in 1948 and formed a constitution in the same year. Korean history begins since the defeat of Japan during the World War II. In 1945, the United Nations divide Korea into two parts, the Soviet Union manage the North of Korean and the United States manage the South of Korean. In 
1948, the Korean government is established, namely South Korea and North Korea. ${ }^{5}$

Republic of Korea (South Korea) was officially established on August 15, 1948 with the full support from United States. At that time, the Syng-Man Rhee was elected as the Republic's first president. ${ }^{6}$ The leadership of Rhee SyngMan is then referred to the First Republic (1953 to 1960$).{ }^{7}$ In the next period, the Democratic Party established the Second Republic (19601961 ) by adopting a parliamentary system. ${ }^{8}$

The third republic period was run in 19631972 and then followed by the Fourth period of Republic on 1972-1979 started since November 21,1972 and was followed by the Fifth Republic period (1979-1987). ${ }^{9}$ The next period of the Sixth Republic was from 1987 to 1992. As for the Constitution of the Republic of Korea since it was founded on July 17, 1948 changed 9 times, they are July 7, 1952, November 29, 1954, June 15, 1960, November 29, 1960, December 261962 , October 21, 1969, December 27, 1972, October 27, 1980 and October 29, 1987.

At the beginning of its formation, the urgency of the Korean Constitutional Court existence as a constitutional court for South Korea is proposed since that time, MA of South Korea is only authorized to review laws against the Constitution, while the matter of the one that should investigate and adjudicate cases dissolution of political parties and the impeachment as well as the case of dispute the authority of institutions state settlement mechanism is not found yet. The establishment of South Korean constitutional court is very much influenced by the German constitutional court system.

Constitutional Court of Korea was established on September 19, 1988. The South Korean constitution drafting team form the Constitutional Court of Korea as one of the independent court beside the Highest Court by adopting the European model. Based on the South Korean

\footnotetext{
Paul Hanley,"Transitional Justice in South Korea: One Country's Restless Search for Truth and Reconciliation," University of Pennsylvania East Asia Law Review, Vol. 9, 2014, Philadelphia: University of Pennsylvania Law School, page 141-142.

6 Ibid., page 142.

7 Ibid
}

Constitution, the Constitutional Court of Korea under Article 107 and Chapter VI which contains three chapters, namely Article 111, Article 112 and Article 113 and followed up with the establishment of The Korean Constitutional Court Act of 1988.

Since it was formed from the first time on August 05, 1988, the Constitutional Court Act of Korea have been amended several times. Some of those changes are, on November 30,1991, December 22, 1994, August 4, 1995, December 13, 1997, January 19, 2002, January 26, 2002, March 12, 2003, March 31, 2005, July 29, 2005, December 21, 2007, March 14, 2008, December 29, 2009, May 4, 2010, and the last is on April 5, 2011.

Regarding to the judicial authority owned by South Korean constitution as mentioned in Article 111 paragraph (1) The Constitution of the Republic Korea and specified by Article 2 The Constitutional Court Act of Korea is the constitutionality of the Act at the request of general courts; Impeachment; dissolution of political parties; authority dispute between state agencies, the state agencies with local governments and between local governments; and a constitutional complaint. Based on the data, 11.679 cases of constitutional complaint had been examined by the Constitutional Court of South Korea. ${ }^{10}$

South Korean constitutional court consists of nine constitutional judges that were sworn in by the president. Maintaining the cases, judges must judge independently and in accordance with the constitution and the law guided by their conscience. Associated with the process of the appointment of constitutional judges South Korea, conducted involving three (3) state institutions, namely the president, the National Assembly and the Chief Justice of the Supreme Court. This is similar to the system used in France to determine the members of the constitutionnel

\footnotetext{
Ibid., page 143.

Ibid., page 146.

10 Hamdan Zoelva, "Pengaduan Konstitusional (Constitutional Complaint) dalam Sistem Peradilan di Indonesia", Jurnal oNegarawan, Jakarta: Sekretariat Negara RI, No. 16, Mei 2010, page 52 .
} 
Conseil or Italian system to appoint 15 judges of the Corte Constituzionale. ${ }^{11}$ The same model is also found in Indonesia.

Based on statistical maintaining the case, the period of 1988-1994, The judicature of South Korea received 2361 cases. A total of 1,897 cases were dealt with details of 262 cases terminated, 1,078 cases in the screening process and 193 cases was withdrawn. A total of 235 decision issued in the period related to the constitutionality of the Act and 59 cases declared unconstitutionality. It means, about 25 percent of the decision resulted in partial repudiation of legislation..$^{12}$ It shows that South Korean constitutional court played a major role uphold the constitution (upholding of the constitution) ${ }^{13}$ as well as contributing to South Korea with a fairly active role through a number of important decisions. ${ }^{14}$

\section{A Comparison of Indonesia and South Korea Constitutional Court Authority}

Generally, there are some similarities between the judicial authority which posse-ssed between Indonesian and South Korea constitutional court. A number of equations authority are to test the laws against the Constitution, rule on the state institutions authority dispute, dissolution of political parties and handle the impeachment cases. The similarities existence of the constitutional court authority between the two countries are understandable by consider the birth of Indonesia's MK is heavily influenced and adopt the constitutional justice system of South Korea.

There are some base differences of the existance from both constitutional justice. The comparison of both constitutional justice sho-

11 Chaihark Hahm, "Beyond 'law vs politics' in Constitutional Adjudication: Lesson from South Korea," International Journal of Constitutional Law, Oxford: Oxford University Press and New York University School of Law, Vol. 10 No. 1, 2012, page 25

12 Kun Yang, "Judicial Review and Social Change in the Korean Democratizing Process," AM. J. COMP. L. Vol. 1, No. 8, 1993, page 41 on Yi-Li Lee, "The Korean Constitutional Court and Kwangju Massacre: Note on the Special Act Concerning the May Democratization Movement Case", National Taiwan University Law Review, Taipei City: National Taiwan University, Vol. 4:2, 2009, page 244. uld be seen from two important aspect. First, from the authority side of each country. Based on authorithy side, the constitutional court authority of South Korea is larger than Indonesia.

This can be evidenced by the authority in maintain cases of constitutional complaint which is owned by the South Korean constitutional court. Such authority is not owned by Indonesian constitutional court as a constitutional authority. Constitutional complaint itself is a right of any person or entity in order to express their opposition to the government's treatment is considered impaired his constitutional rights. ${ }^{15}$ Through the of the constitutional complaint authority implementation, the constitutional right of the public will be better protected.

Placement of the constitutional complaint authority as a judicial authority of the constitution as applied in South Korea should be interpreted as an effort to establish a constitutional court to maintain while interpreting the constitution. Through these powers, a constitutional court can play a role in ensuring the enforcement of the constitution. The absence of the authority of constitutional complaint Indonesian constitutional court in principle is one of the fundamental weaknesses in the judicial system of a constitution adopted in Indonesia.

Second, in terms of the implementation of the authority. Despite there are some similarities found in constitutional authority owned by Indonesian and South Korean constitutional court, however, there are some differences found in the implementation of the authority. One of the difference is in the authority implementation referred to judicial review. Based on the implementation of the judicial review au-

13 Jinsu Yune, "Tradition and the Constitution in the Context of the Korean Family Law", Journal of Korean Law, Seoul: College of Law, Seoul National University (SNU), Vol. 5 No. 1, 2005, page 194.

14 Kong Hyun Lee, "Constitutional Review, Social Change and Global Cooperation: Experience of Korea," World Conference on Constitutional Justice, Cape Town, 23-24 January 2009, page 2 .

15 Vino Devanta Anjas Krisdanar, “Menggagas Constitutional Complaint dalam Memproteksi Hak Konstitusional Masyarakat Mengenai Kehidupan Kebebasan Beragama di Indonesia", Jurnal Konstitusi, Vol. 7 No. 3 June 2010, Jakarta: MK RI, page 190. 
thorities model in South Korea, the general courts is the one which may submit a case for judicial review to the Constitutional Court of Korea.

Unlike the case in the state of Indonesia, a case for judicial review may be filed by an individual Indonesian citizen; customary law community unit along still alive and in accordance with the development of society and the principle of the unitary state of Indonesia stipulated in the Act; public or private legal entities; or a state Institution. Based on this context, there is an expansion of the parties that have the legal standing as an applicant, so that it can be said that the model is run in Indonesia is more comprehensive as well as more opportunities for broad participation in judicial review.

Another difference is in the state institutions settlement dispute authority implementation. In Indonesia, the party which has legal standing in the case of an authority dispute of state institutions only the state institutions whose authorities are granted by the Constitution. Further the Court Regulation 8 of 2006 stated that the applicant can be in a case of dispute the state institutions authority which are the House of Representatives, the Assembly, the President, CPC, local government and other institutions whose authorities are granted by the Constitution.

Such limitation model actually unclear and difficult to understand. Because, in the Constitution NRI of 1945 itself, there were no equality regarding to the terms of state institutions and agencies which can be categorized as a state institution. In addition, there is also no assertiveness on the authority granted by the Constitution, whether direct granted authority or including the indirectly granted authority.

Unlike the implementation of dispute settlement authority in South Korea, classifications is made by the following: dispute the authority of state institutions, which is the authority dis-

16 Article 62 paragraph (1) The Constitutional Court Act of Korea.

17 Muchamad Ali Safa'at, et.al, 2010, Hukum Acara Mahkamah Konstitusi, Jakarta: Sekretariat Jenderal Mahkamah Konstitusi Republik Indonesia in coorperrated with Aso- pute between the National Assembly, the Executive, ordinary court and the National Election Commission; authority dispute between state institutions to local government, namely, first, the dispute between the executive authority with the Special Metropolitan City, Metropolitan City or Province; and second, the dispute between the executive and local authorities (district/city); disputes between the local government authority, the authority dispute between the Special Metropolitan City, Metropolitan City or Province and the second, authority dispute between the district/city; and the authority dispute between the Special Metropolitan City, Metropolitan City or Province and the City, County or Self-governing District. ${ }^{16}$

Regarding to the disputed authority, in South Korea there is no limitation of the state institutions disputed authority whether it must be granted by the Constitution or not. This is in contrast with the case of a dispute settlement authority between state institutions in Indonesia, where the disputed authority only the authority which is given by the Constitution. Constitutional Court of Korea in maintain dispute settlement authority of state institutions can freeze the activity of state agencies were sued until the final verdict issued by the Constitutional Court of Korea. ${ }^{17}$ As for maintain the authority, the Constitutional Court of Korea adopt a substantive and procedural process. ${ }^{18}$ More details regarding to the comparison of a constitutional court between Indonesia and South Korea can be seen in the following matrix.

\begin{tabular}{|c|c|l|}
\hline No & Description & $\begin{array}{l}\text { Constitutional Court of Indonesia } \\
\text { and South Korea }\end{array}$ \\
\hline 1 & Similarities & $\begin{array}{l}\text { Both have the authority to test Act } \\
\text { against the Constitution, to deciede } \\
\text { the dispute authority of state institu- } \\
\text { tions, dissolution of political parties } \\
\text { and maintain the impeachment cases. }\end{array}$ \\
\hline 2 & Differences & $\begin{array}{l}\text { South Korean constitutional court has } \\
\text { the authority to deal with the consti- } \\
\text { tutional complaint, while the Indone- } \\
\text { sian constitutional court doesn't have } \\
\text { those authority }\end{array}$ \\
\hline
\end{tabular}

siasi Pengajar Hukum Acara Mahkamah Konstitusi, page 154.

18 Jibong Lim, "Korean Constitutional Court and Due Process Clause," Journal of Korean Law, Seoul: College of Law, Seoul National University (SNU), Vol. 6 No. 1, 2006, page 11. 


\begin{tabular}{|c|c|c|}
\hline & & $\begin{array}{l}\text { In South Korea, the one which can liti- } \\
\text { gate the judicial review is the general } \\
\text { court, while in Indonesia is the indivi- } \\
\text { dual state society; customary law } \\
\text { community until still alive and in ac- } \\
\text { cordance with the development of so- } \\
\text { ciety and the Homeland principles sti- } \\
\text { pulated in the Act. } \\
\text { In Indonesia, the cases of dispute au- } \\
\text { thority of state institutions, which } \\
\text { can be the applicant is limited to sta- } \\
\text { te institution which authority is gran- } \\
\text { ted by the Constitution, while in } \\
\text { South Korea there is no restrictions. }\end{array}$ \\
\hline 3 & $\begin{array}{l}\text { The } \\
\text { Excellences }\end{array}$ & $\begin{array}{l}\text { South Korea constitutional court is } \\
\text { more superior in the field of authority } \\
\text { possessed, which is the authority in } \\
\text { the matter of the constitutional com- } \\
\text { plaint and the classification of the au- } \\
\text { thority dispute. While, the Indonesia } \\
\text { constitutional court more superior in } \\
\text { the implementation of the judicial } \\
\text { authority, because the one that can } \\
\text { be the applicant in the case is broader } \\
\text { scope. }\end{array}$ \\
\hline 4 & $\begin{array}{l}\text { The } \\
\text { weaknesses }\end{array}$ & $\begin{array}{l}\text { Indonesian constitutional court does } \\
\text { not have jurisdiction of constitutional } \\
\text { complaint and there is no classifica- } \\
\text { tion dispute the authority of state ins- } \\
\text { titutions. One of the weakness of } \\
\text { South Korea constitutional court was } \\
\text { not found the authority limitation of } \\
\text { state institutions that can be disputed } \\
\text { in the dispute of authority, whether it } \\
\text { should be given by the Constitution of } \\
\text { not. }\end{array}$ \\
\hline
\end{tabular}

The implementation of dispute settlement authority of state institutions by Korean Constitutional Court is more comprehensive than Indonesia. For example, a dispute authorities involving the local government are not categorized as an authority dispute of state institutions, as applied in Indonesia. This should be a separate record for Indonesia to make a corrections related to the constitutional court implementation with the authority to refer a number of plusowned by South Korean constitutional court. The settling is expected to be done by maintaining a number of advantages that have been owned by the Indonesian Constitutional Court.

\section{Closing}

Summary

A comparison of constitutional court between Indonesia and South Korea can be found through some similarities and differences of both constitutional court. Constitutional court of both countries have the same authority to judicial review, rule on the dispute the authority of state institutions, the dissolution of political parties and the impeachment. The difference is that the South Korean constitutional court has the authority to conduct constitutional complaint, while the Indonesian constitutional court has no authority on it. Moreover, in the implementation of judicial review authority, the applied model in the Indonesian constitutional court is more comprehensive than the models applied to South Korean constitutional court. However, the opposite occurred in the implementation of the authority to decide the dispute the authority of state institutions, where the model applied in South Korea is more superior compared with dispute settlement authority state institutions in Indonesia.

\section{Suggestion}

Referring to a number of differences, Indonesia should adopted some advantages of South Korean constitutional court in order to maximize the presence of Constitutional Court as the guardian, keeper, enforcement and interpreter of the Constitution, while some advantages of MK of Indonesia would be maintained, so that the efforts of adoption is only as the complementary and enhance the constitutional court models that applied in Indonesia.

\section{References}

Hahm, Chaihark. "Beyond 'law vs politics' in Constitutional Adjudication: Lesson from South Korea". International Journal of Constitutional Law, Vol. 10 No. 1, 2012. Oxford: Oxford University Press and New York University School of Law;

Hanley, Paul."Transitional Justice in South Korea: One Country's Restless Search for Truth and Reconciliation". University of Pennsylvania East Asia Law Review, Vol. 9, 2014. Philadelphia: University of Pennsylvania;

Krisdanar, Vino Devanta Anjas. "Menggagas Constitutional Complaint dalam Memproteksi Hak Konstitusional Masyarakat Mengenai Kehidupan Kebebasan Beragama di Indonesia". Journal of Konstitusi, Vol. 7 No. 3 Edisi Juni 2010. Jakarta: MK RI; 
Lee, Kong Hyun. Constitutional Review, Social Change and Global Cooperation: Experience of Korea. World Conference on Constitutional Justice, Cape Town, $23^{\text {rd }}-24^{\text {th }}$ of January 2009;

Lim, Jibong. "Korean Constitutional Court and Due Process Clause". Journal of Korean Law, Vol. 6 No. 1, 2006, Seoul: College of Law, Seoul National University (SNU);

Mahkamah Konstitusi. "Rekapitulasi Perkara Pengujian Undang-Undang". available on website http://www.mahkamahkonstitusi.go.id/index.php?page=web. RekapPUU, accessed on $14^{\text {th }}$ of November 2015;

Pigome, Martha. "Implementasi Prinsip Demokrasi dan Nomokrasi dalam Struktur Ketatanegaraan RI Pasca Amandemen UUD 1945," Journal Dinamika Hukum, Vol. 11 No. 2, May 2011. Purwokerto: Law Faculty of Jenderal Soedirman University;

Safa'at, Muchamad Ali, et.al, 2010, Hukum Acara Mahkamah Konstitusi, Jakarta: Sekretariat Jenderal Mahkamah Konstitusi Republik Indonesia bekerjasama dengan Asosiasi Pengajar Hukum Acara Mahkamah Konstitusi;

Simamora, Janpatar. "Tafsir Makna Negara Hukum dalam Perspektif Undang-Undang Dasar Negara Republik Indonesia Tahun 1945", Journal of Dinamika Hukum, Vol. 14 No. 3 September 2014. Purwokerto: Law Faculty of Jenderal Soedirman University;

...-... “Analisa Yuridis Terhadap Model Kewenangan Judicial Review di Indonesia". Jurnal Mimbar Hukum, Vol. 25 No. 3 October 2013. Yogyakarta: Law Faculty of Gadjah Mada University;

Yang, Kun, on Lee, Yi-Li. "The Korean Constitutional Court and Kwangju Massacre: Note on the Special Act Concerning the May Democratization Movement Case". National Taiwan University Law Review, Vol. 4:2, 2009. Taipei City: National Taiwan University;

Yune, Jinsu. "Tradition and the Constitution in the Context of the Korean Family Law". Journal of Korean Law, Vol. 5 No. 1, 2005. Seoul: College of Law, Seoul National University (SNU);

Zoelva, Hamdan. "Pengaduan Konstitusional (Constitutional Complaint) dalam Sistem Peradilan di Indonesia", Jurnal of Negara- wan, No. 16, May 2010, Jakarta: Sekretariat Negara RI. 